\title{
Is CEUS the future for imaging complex renal cysts? Are we on the threshold of a change?
}

\author{
Ist CEUS die Zukunft in der Bildgebung komplexer Nierenzysten? Stehen wir an \\ der Schwelle zur Veränderung?
}

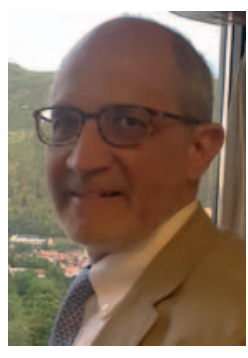

Prof. Paul S. Sidhu

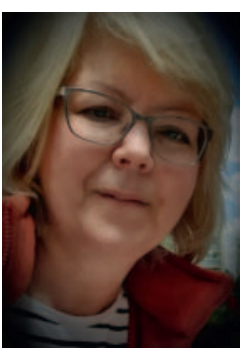

Jolanta Webb

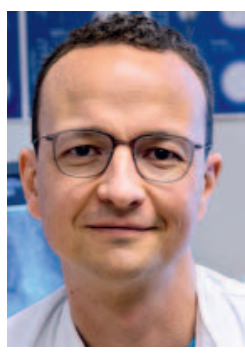

Ole Graumann
Correspondence

Prof. Paul S. Sidhu

King's College London - Radiology

King's College Hospital, Denmark Hill, London SE5 9RS,

United Kingdom of Great Britain and Northern Ireland

Tel.: +44/2 03/2994164

Fax: $+44 / 2$ 03/2993157

paulsidhu@nhs.net
Bibliography

Ultraschall in Med 2021; 42: 344-346

DOI 10.1055/a-1511-9997

ISSN $0172-4614$

(c) 2021. Thieme. All rights reserved.

Georg Thieme Verlag KG, Rüdigerstraße 14,

70469 Stuttgart, Germany
The paper by Gasser et al in this issue compares the cost-effectiveness of contrast-enhanced ultrasound (CEUS) with magnetic resonance (MR) imaging as a diagnostic option for indeterminate cystic renal lesions [1]. The cost-effectiveness of CEUS has also been investigated and reported recently by Spiesecke at al., adding contrast enhanced computed tomography (CECT) along with MR imaging, demonstrating the clear cost-effectiveness of CEUS [2]. An EFSUMB 2020 position statement, examining the evidence for the use of CEUS in the assessment of complex renal cysts, ascertained the usefulness of this technique when applying the CECT based Bosniak classification [3]. Are we therefore on the threshold of a change in clinical practice in relation to the diagnostic management of a complex renal cyst?

The categorisation of complex renal cysts, according to their malignant potential, introduced by Bosniak in 1986 as a CT classification [4] is an enduring legacy, established in the infancy of CT techniques and prior to the expansion of ultrasound and MR imaging. All imaging modalities are now so much more sophisticated, likely to continue to develop and improve, with the potential to rationalise established imaging pathways. A recent major revision of Bosniak classification brings CECT based complex renal cyst assessment into the $21^{\text {st }}$ century complete with a Bosniak calculator "app" [5], and the inclusion of MR imaging providing its further refinement [6]. The application of CEUS to the complex renal cyst is the most logical extension to the armamentarium of the imaging specialist, likely to achieve the ultimate accolade of the "reference" standard for the presence or absence of vascularization in a complex renal cyst, and was predicted by Bosniak himself [7].

There are advantages and disadvantages to CT, MR and CEUS in the assessment of a complex renal cyst; the accurate assessment is crucial, as the rate of malignancy increases with the degree of complexity of the renal cyst, and the Bosniak IIF and III lesions are the key lesions that warrant detailed investigation and management [8]. Follow-up for Bosniak IIF and III lesion is more cost-effective than surgery, with the current mainstay of assessment with a CECT examination [9]. The well-known accuracy of a CECT examination is tempered by the burden of accumulated radiation dose with follow-up imaging and inherent risks of iodinated contrast, and the pitfall of pseudo-enhancement of a lesion. With MR imaging, the limitations include motion artefacts, lower spatial resolution, variable image quality and the uncertainty of the long-term effects of gadoliniumbased contrast media. Both CT and MR imaging have high inherent costs for the equipment purchase and installation, staffing and maintenance. The advantage with both $C T$ and MR imaging is the panoramic global view of the abdominal contents and established imaging credentials. Ultrasound is relatively inexpensive to purchase and install, almost the "plug-and-play" imaging modality, and with potential to be moved anywhere to undertake an examination.

The updated 2019 Bosniak classification of complex cysts formally incorporates MR criteria but does not assess the utility of 
CEUS in assessing complex renal cysts in any detail [5]. B-mode ultrasound has excellent spatial and temporal resolution, allowing for the clear depiction of septae, and the addition of ultrasound contrast, the only truly intravascular contrast agent, depicts vascularity accurately with an established safety profile. This is tempered against the inability of ultrasound to view in a global fashion; some lesions will not be visualised. Nevertheless, taking vascularity and enhancement with contrast as the hallmark of malignancy, CEUS has the potential to outperform both CT and MR imaging, not forgetting the real time imaging of a CEUS examination that negates contrast timing issues. The upgrading and downgrading of complex renal cysts will occur, and the need to follow-up these lesions will be significantly altered by this approach $[10,11]$.

Changing clinical practice, particularly the one embedded since 1986 will take time. The strengths of MR, CT and CEUS imaging in assessing complex renal cysts should be harnessed to formulate a robust and safe management pathway for the patient, dispensing with entrenched practices. Unfortunately, incorporating CEUS into clinical practice is hampered by the lack of a product license for renal applications, limiting reimbursement in some health systems, but this does not preclude its use [12]. The clear case for CEUS is in the follow-up imaging of the Bosniak IIF and III complex renal cyst, that have been visualised on a previous CT or ultrasound examination. The CEUS examination will ascertain the vascularity of even the thinnest of septae, establish the thickness and morphology of the septae and cyst wall which may downgrade or upgrade the cyst. The ability to follow-up the single isolated complex renal cyst with an imaging technique that is patient friendly, cost-effective, safe from radiation and complications of the administered contrast agent would be extremely attractive to our customer, the patient, even if outside the "comfort" zone of the medical imager. The informed patient, keen also to avoid unnecessary surgery, will give direction to the ideal management pathway, rather than the entrenched practitioner. This is already reflected in imaging practices where the practitioner is not a radiologist, with less timely access to CT and MR techniques, who already deploys ultrasound to the maximum ability; ultrasound and CEUS will become more established in managing the complex renal cyst.

Ideally the patient journey through the complex cyst assessment will change, less reliant on CT and MR imaging in the diagnosis and follow-up, with CEUS becoming established as the optimal imaging technique. The most obvious first step in this direction is the confirmation of a CT or MR imaged Bosniak IIF and III lesion which requires follow-up, and to perform this follow-up in a CEUS targeted program without the need for 5 years of radiation exposure. This seems to be logical - a "no-brainer" in the language of the customer, our patient.

\section{Ist CEUS die Zukunft in der Bildgebung komplexer Nierenzysten? Stehen wir an der Schwelle zur Veränderung?}

In dieser Ausgabe vergleichen Gasser et al. die Kosteneffektivität des kontrastverstärkten Ultraschalls (CEUS) mit der Magnetresonanztomografie (MR) als Diagnosemöglichkeit bei unklaren zysti- schen Nierenläsionen [1]. Die Kosteneffektivität des CEUS wurde ebenfalls kürzlich von Spiesecke at al. untersucht und vorgestellt. Sie fügten die kontrastverstärkte Computertomografie (CECT) der MR-Bildgebung hinzu und zeigten eine deutliche Kosteneffektivität des CEUS [2]. Eine Stellungnahme der EFSUMB 2020, in der die Evidenz für den Einsatz des CEUS bei der Beurteilung komplexer Nierenzysten untersucht wurde, stellte den Wert dieser Technik bei der Anwendung der CECT-basierten Bosniak-Klassifikation fest [3]. Stehen wir daher an der Schwelle zur Veränderung der klinischen Praxis beim diagnostischen Management einer komplexen Nierenzyste?

Die 1986 von Bosniak als CT-Klassifikation eingeführte Einteilung komplexer Nierenzysten nach ihrem malignen Potenzial [4] ist ein dauerhaftes Erbe, das in den Anfängen der CT-Technologie und vor Expansion der Ultraschall- und MR-Bildgebung etabliert wurde. Alle bildgebenden Verfahren sind heute so viel ausgereifter; sie werden sich wahrscheinlich weiterentwickeln und verbessern und haben das Potenzial, etablierte Wege in der Bildgebung zu rationalisieren. Eine kürzlich durchgeführte, umfassende Überarbeitung der Bosniak-Klassifikation führt die CECT-basierte Beurteilung komplexer Nierenzysten in das 21. Jahrhundert. Diese bietet durch die Komplettierung mit einer Bosniak-Rechner- „App“ [5] und durch die Einbeziehung der MR-Bildgebung weitere Präzisierungen [6]. Die CEUS-Anwendung bei der komplexen Nierenzyste ist die sinnvollste Ergänzung des Instrumentariums des Bildgebungsspezialisten. Sie wird wahrscheinlich als ultimativer Ritterschlag gelten, was den „Referenzstandard“ für das Vorhandensein oder Fehlen einer Vaskularisation der komplexen Nierenzyste anbelangt, und wurde von Bosniak selbst vorausgesagt [7].

Bei der Beurteilung einer komplexen Nierenzyste haben CT, MR und CEUS Vor- und Nachteile. Die genaue Beurteilung ist entscheidend, da die Malignitätsrate mit dem Komplexitätsgrad der Nierenzyste zunimmt und die Bosniak-IIF- und -III-Läsionen die Schlüsselläsionen sind, die eine detaillierte Untersuchung und Behandlung rechtfertigen [8]. Die Nachsorge bei Bosniak-IIF- und -III-Läsionen ist kosteneffektiver als eine Operation, wobei derzeit die Beurteilung mittels CECT-Untersuchung im Vordergrund steht [9]. Der bekannten Genauigkeit einer CECT-Untersuchung stehen die Belastung durch die akkumulierte Strahlendosis bei der Nachuntersuchung, die inhärenten Risiken des jodhaltigen Kontrastmittels und die Fehlinterpretation eines Pseudo-Enhancements einer Läsion gegenüber. Zu den Einschränkungen der MRBildgebung gehören Bewegungsartefakte, eine geringere räumliche Auflösung, eine variable Bildqualität und die Unsicherheit hinsichtlich der Langzeitwirkung von Gadolinium-basierten Kontrastmitteln. Sowohl die CT- als auch die MR-Bildgebung sind mit hohen Eigenkosten für die Anschaffung und Installation der Geräte sowie für Personal und Wartung verbunden. Die Vorteile sowohl bei der CT- als auch bei der MR-Bildgebung sind der panoramische „Global View“ des Bauchinhalts und die etablierten Bildgebungsnachweise. Ultraschall ist relativ kostengünstig in der Anschaffung und Installation, fast ein „Plug-and-Play“-Bildgebungsverfahren und kann für eine Untersuchung überall hin transportiert werden.

Die 2019 aktualisierte Bosniak-Klassifikation komplexer Zysten bezieht ausdrücklich MR-Kriterien mit ein, bewertet aber den Nutzen des CEUS bei der Beurteilung komplexer Nierenzysten nicht 
im Detail [5]. Die B-Bild-Sonografie hat eine ausgezeichnete räumliche und zeitliche Auflösung, die eine klare Darstellung von Septen ermöglicht, und die Zugabe von Ultraschallkontrastmittel, dem einzigen wirklich intravaskulären Kontrastmittel, stellt die Vaskularisation mit einem etablierten Sicherheitsprofil genau dar. Dem steht die Unfähigkeit des Ultraschalls gegenüber, eine globale Betrachtung vorzunehmen; einige Läsionen können nicht visualisiert werden. Wenn man jedoch Vaskularisation und Kontrastmittelanreicherung als Marker für Malignität betrachtet, so hat CEUS das Potenzial, sowohl die CT- als auch die MR-Bildgebung zu übertreffen. Nicht zu vergessen ist auch, dass die Echtzeit-Bildgebung einer CEUS-Untersuchung die Probleme mit dem Timing des Kontrastmittels aufhebt. Eine Up- und Downgrading komplexer Nierenzysten wird erfolgen und die Notwendigkeit der Nachsorge dieser Läsionen wird sich durch diesen Ansatz erheblich verändern $[10,11]$.

Die Veränderung der klinischen Praxis, insbesondere seit dem Jahr 1986, wird Zeit in Anspruch nehmen. Die Stärken der MR-, CT- und CEUS-Bildgebung bei der Beurteilung komplexer Nierenzysten sollten genutzt werden, um einen belastbaren und sicheren Behandlungspfad für den Patienten auszuarbeiten, der auf eingefahrene Praktiken verzichtet. Leider wird die Integration von CEUS in die klinische Praxis durch das Fehlen einer Produktzulassung für renale Anwendungen erschwert, was die Kostenerstattung in einigen Gesundheitssystemen einschränkt - das schließt allerdings dessen Einsatz nicht aus [12]. Ein eindeutiger Fall für CEUS stellt die Nachsorge der komplexen Nierenzysten BosniakIIF und -III dar, die bei einer vorherigen CT- oder Ultraschalluntersuchung visualisiert wurden. Die CEUS-Untersuchung stellt die Vaskularisation selbst der dünnsten Septen fest und bestimmt die Dicke und Morphologie der Septen und der Zystenwand, was zu einem Downgrading oder Upgrading der Zyste führen kann. Die Möglichkeit, eine einzelne isolierte komplexe Nierenzyste mit einem patientenfreundlichen, kostengünstigen, strahlen- und komplikationssicheren bildgebenden Verfahren nachzuverfolgen, ist für unseren Kunden, den Patienten, äußerst attraktiv, selbst wenn dies außerhalb der „Komfortzone“ des für die Bildgebung zuständigen Arztes ist. Der informierte Patient, der darauf bedacht ist, unnötige Operationen zu vermeiden, wird den idealen Behandlungspfad vorgeben, und nicht der maßgebende Arzt. Dies spiegelt sich bereits in der Praxis der Bildgebung wider, wenn der Arzt kein Radiologe ist, denn dieser hat nicht so zeitnah Zugang zu CT- und MR-Techniken und setzt Ultraschall bereits optimal ein. Ultraschall und CEUS werden sich beim Management der komplexen Nierenzyste stärker etablieren.

Idealerweise wird sich die „Patient Journey“ durch die Beurteilung der komplexen Zyste verändern, sodass Diagnose und Nachsorge weniger auf der CT- und MR-Bildgebung beruhen und sich CEUS als optimales bildgebendes Verfahren etabliert. Die offensich- tlichsten erste Schritte in diese Richtung sind die Bestätigung einer in CT oder MR dargestellten Bosniak-IIF- und -III-Läsion, die eine Nachsorge erfordert, und dass diese Untersuchungen mit einem gezielten CEUS-Programm über 5 Jahre ohne Strahlenbelastung durchgeführt werden.

Im „Klartext gesprochen“- der Sprache des Kunden, unseres Patienten - ist dies nur logisch.

Conflict of Interest

Paul Sidhu has received lecture fees from Bracco, Samsung and Siemens.

\section{References}

[1] Gassert F, Schnitzer M, Kim SH et al. Comparison of Magnetic Resonance Imaging and Contrast-Enhanced Ultrasound as Diagnostic Options for Unclear Cystic Renal Lesions: A Cost-Effectiveness Analysis. Ultraschall in Med 2020. doi:10.1055/a-1110-7172. Epub ahead of print. PMID: 32052386

[2] Spiesecke P, Reinhold T, Wehrenberg Y et al. Cost-effectiveness analysis of multiple imaging modalities in diagnosis and follow-up of intermediate complex cystic renal lesions. BJU International. 2021. Feb 2 [e-pub]

[3] Cantisani V, Bertolotto M, Clevert DA et al. EFSUMB 2020 Proposal for a Contrast-Enhanced Ultrasound-Adapted Bosniak Cyst Categorization: Position Statement. Ultraschall in Med 2021; 42 (2): 154-166

[4] Bosniak MA. The current radiological approach to renal cysts. Radiology 1986; 158 (1): 1-10

[5] Silverman SG, Pedrosa I, Ellis JH et al. Bosniak Classification of Cystic Renal Masses, Version 2019: An Update Proposal and Needs Assessment. Radiology 2019; 292 (2): 475-488

[6] Krishna S, Schieda N, Pedrosa I et al. Update on MRI of Cystic Renal Masses Including Bosniak Version 2019. J Magn Reson Imaging. 2020. Oct 2 [e-pub]

[7] Bosniak MA. The Bosniak Renal Cyst Classification: 25 Years Later. Radiology 2012; 262: 781-785

[8] Schoots IG, Zaccai K, Hunink MG et al. Bosniak Classification for Complex Renal Cysts Reevaluated: A Systematic Review. Journal of Urology 2017; 198 (1): 12-21

[9] Smith AD, Carson JD, Sirous R et al. Active Surveillance Versus NephronSparing Surgery for a Bosniak IIF or III Renal Cyst: A Cost-Effectiveness Analysis. Am J Roentgenol 2019; 212 (4): 830-838

[10] Graumann O, Osther SS, Karstoft J et al. Bosniak classification system: a prospective comparison of CT, contrast-enhanced US, and MR for categorizing complex renal cystic masses. Acta Radiologica 2015; 57 (11): 1409-1417

[11] Barr RG. Is there a need to modify the Bosnaik renal mass classification with the addition of contrast-enhanced sonography? J Ultrasound Med 2017; 36: 865-868

[12] Sidhu PS, Choi BI, Bachmann NM. The EFSUMB guidelines and recommendations on the clinical practice of contrast enhanced ultrasound (CEUS): a new dawn for the escalating use of this ubiquitous technique. Ultraschall in Med 2012; 32: 5-7 